\title{
TINJAUAN HUKUM PENDAFTARAN TANAH SECARA SISTEMATIS MELALUI AJUDIKASI BERDASARKAN PP NO. 24 TAHUN 1997
}

\author{
Raras Laila Yustinov, Fitika Andraini \\ Fakultas Hukum, Universitas Stikubank (UNISBANK) Semarang \\ E-mail : raraslaila8@gmail.com, fitika@edu.unisbank.ac.id
}

\begin{abstract}
ABSTRAK
Kebutuhan tanah terus meningkat sehingga sering menimbulkan masalah yang amat kompleks. Untuk menangani masalah pertanahan tersebut, pemerintah menerbitkan Undang-Undang No. 5 tahun 1960 tentang Peraturan Dasar Pokok-Pokok Agraria yang kemudian dikenal dengan UUPA, lahirnya UUPA merupakan tonggak baru bangsa ini dalam hukum pertanahan. Sejalan dengan itu pemerintah kemudian mengeluarkan peraturan pemerintah No 24 Tahun 1997 tentang pendaftaran tanah yang kembali menegaskan pentingnya masyarakat mendaftarkan tanahnya, pendaftaran tanah berfungsi untuk mengetahui status bidang tanah, siapa pemiliknya, apa haknya, berapa luasnya, untuk apa dipergunakan. Pentingnya diadakannya pendaftaran tanah secara sistematis, baik dan benar melalui ajudikasi bertujuan untuk mengurangi masalah yang timbul berkaitan dengan tanah.

Metode Penelitian yang digunakan penulis metode pendekatan yang bersifat yuridis empiris dengan maksud membuktikan atau menguji untuk memastikan kebenaran dan merasionalkannya melalui hasil penelitian dan pengalaman yang telah ditemukan dalam kehidupan sehari-hari. Hasil penelitian yang ditemukan bahwa masyarakat lebih banyak mendaftarkan tanahnya dengan cara sporadic, karena masyarakat menganggap pendaftaran tanah secara sistematis belum tentu ada setiap tahunnya, meskipun mahal masyarakat tetap mendaftarkan tanahnya demi mendapatkan hak atas tanah yang dimilikinya.
\end{abstract}

Kata kunci : PP No. 24 Tahun 1997, Pendaftaran tanah, Ajudikasi 


\begin{abstract}
The need for land continues to increase so that it often causes very complex problems. To deal with these land issues, the government issued Law no. 5 of 1960 concerning Basic Agrarian Principles which later became known as the UUPA, the birth of the UUPA was a new milestone for this nation in land law. In line with that, the government then issued government regulation No. 24 of 1997 concerning land registration which reaffirmed the importance of the community registering their land, land registration functions to find out the status of the land parcels, who owns it, what rights are it, how much area, what is it used for. The importance of systematic, good and correct land registration through adjudication aims to reduce problems that arise with regard to land.

The research method used by the writer is a juridical empirical approach with the intention of proving or testing to ensure the truth and rationalizing it through the results of research and experiences that have been found in everyday life. The results of the research found that more people register their land in a sporadic manner, because the community considers that systematic land registration does not necessarily occur every year, even though it is expensive for the community to register their land in order to obtain the rights to the land they own.
\end{abstract}

Keywords: PP No. 24 of 1997, land registration, adjudication 


\section{Pendahuluan}

Pendaftaran tanah berasal dari kata Cadastre (bahasa Belanda Kadaster) suatu istilah teknis untuk suatu rekord (rekaman), menunjukan kepada luas, nilai dan kepemilikan (atau lain - lain alas hak) terhadap suatu bidang tanah. Kata ini berasal dari bahasa latin "capitastrum" yang berarti suatu register atau capita atau unit yang diperbuat untuk pajak tanah romawi (Capotatio Torrens). Dalam artian yang tegas cadastre adalah rekord (rekaman daripada lahan-lahan, nilai-nilai daripada tanah dan pemegang haknya dan untuk kepentingan perpajakan). ${ }^{1}$

Pendaftaran tanah adalah suatu rangkaian kegiatan, yang di lakukan oleh negara / pemerintah secara terus menerus dan teratur, berupa pengumpulan keterangan atau data tertentu mengenai tanah - tanah tertentu yang ada di wilayah wilayah tertentu, pengolahan, penyimpanan dan penyajiannya bagi kepentingan rakyat, dalam rangka memberikan jaminan kepastian hukum di bidang pertanahan, termaksud penerbitan tanda-buktinya dalam pemeliharaanya.

Kata - kata " suatu rangkaian kegiatan " menunjuk kepada adanya berbagai kegiatan dalam penyelenggaraan pendaftaran tanah, yang berkaitan satu dengan yang lain, berurutan menjadi satu kesatuan rangkaian yang bermuara pada tersedianya data yang di perlukan dalam rangka memberikan jaminan kepastian hukum di bidang pertanahan bagi rakyat.

${ }^{1}$ A.P. Parlindungan, Pendaftaran Tanah di Indonesia, Mandar Maju, Bandung 1999, $\mathrm{h} \operatorname{lm} 18$.
Kata "terus menerus" menunjuk kepada pelaksanaan kegiatan, yang sekali dimulai tidak akan ada akhirnya. Data yang sudah terkumpul dan tersedia harus selalu dipelihara, dalam arti disesuaikan dengan perubahan perubahan yang terjadi kemudian, hingga tetap sesuai dengan keadaan terakhir undangan yang sesuai, karena hasilnya akan merupakan data bukti menurut hukum, biarpun daya kekuatan pembuktiannya tidak selalu sama dalam hukum negara-negara yang menyelenggarakan pendaftaran tanah.

Salah satu aturan yang mengatur tentang pendaftaran tanah adalah Undang-Undang Pokok Agraria (UUPA), UUPA merupakan peraturan dasar yang mengatur penguasaan, pemilikan, peruntukan, penggunaan, dan pengendalian pemanfaatan tanah yang bertujuan terselenggaranya pengelolaan dan pemanfaatan tanah untuk sebesarbesar kemakmuran rakyat. Salah satu aspek yang dibutuhkan untuk tujuan tersebut adalah mengenai kepastian hak atas tanah yang menjadi dasar utama dalam rangka kepastian hukum kepemilikan tanah. ${ }^{2}$

Diberlakukannya UUPA merupakan awal sejarah perkembangan Hukum Agraria di Indonesia, khususnya mengenai Hukum di bidang pertanahan dan menghapus dualisme. Kata "teratur" menunjukan, bahwa semua kegiatan harus berlandaskan peraturan perundang - undangan hukum pertanahan. Untuk menjamin

\footnotetext{
${ }^{2}$ Boedi Harsono, Hukum Agraria Indonesia Sejarah Pembentukan Undang - Undang Pokok Agraria, Isi dan Pelaksanaannya, Jakarta : Djambatan, 2005, hlm $72-73$
} 
kepastian hukum tersebut, UUPA menegaskan dalam Pasal 19 Ayat (1) yang berbunyi:

"Untuk menjamin kepastian hukum olehpemerintah diadakannya

Pendaftaran Tanah di seluruh wilayah Indonesia menurut ketentuan yang diatur dengan Peraturan Pemerintah".

Berpatokan

pada

perkembangan yang begitu pesat dan banyaknya persoalan pendaftaran tanah yang muncul ke permukaan dan tidak mampu diselesaikan oleh Peraturan Pemerintah Nomor 10 Tahun 1961, maka setelah berlaku selama kurang lebih 38 tahun, untuk selanjutnya pemerintah telah mengeluarkan Peraturan Pemerintah Nomor 24 Tahun 1997 tentang Pendaftaran Tanah. ${ }^{3}$

Pendaftaran tanah yang diatur dalam Peraturan Pemerintah No. 24 Tahun 1997 tentang pendaftaran tanah dilaksanakan berdasarkan azas sederhana, aman, terjangkau, mutakhir dan terbuka. ${ }^{4}$

Kegiatan Pendaftaran tanah meliputi kegiatan pendaftaran tanah untuk pertama kali dan kegiatan pemeliharaan data yang tersedia. Pendaftaran tanah untuk pertama kali ("initial registrasion") meliputi tiga bidang kegiatan, yaitu: bidang fisik atau "teknis kadastral", bidang yuridis dan penerbitan dokumen tanda-bukti hak.

Kegiatan pendaftaran tanah untuk pertama kali ("initial registration") dapat di lakukan melalui dua cara, yaitu secara

${ }^{3}$ Supriyadi, Hukum Agraria, Sinar Grafika, cetakan ke dua, Jakarta 2008, hlm 152 153

${ }^{4}$ Supriyadi, Hukum Agraria, Sinar Grafik, cetakan pertama, Jakarta, 2007, hlm 64 sistematis dan secara sporadik. Pendaftaran tanah secara sistematis adalah kegiatan pendaftaran tanah untuk pertama kali yang dilakukan secara serentak yang meliputi semua objek pendaftaran tanah yang belum di daftar dalam wilayah atau bagian wilayah suatau desa atau kelurahan, umumnya prakarsa datang dari pemerintah yang diatur dalam Peraturan Menteri Negara Agraria / Kepala BPN No. 3 Tahun 1995 tentang penyelenggaraan Pendaftaran Tanah Secara Sistematik. Pendaftaran tanah secara sporadik adalah kegiatan pendaftaran tanah untuk pertama kali mengenai satu atau beberapa objek pendaftaran tanah dalam wilayah atau bagian wilayah satu desa atau kelurahan secara individual atau massal, yang dilakukan atas permintaan pemegang atau penerima hak atas tanah yang bersangkutan.

Pendaftaran tanah secara sistematik lebih diutamakan karena melalui cara ini akan dipercepat perolehan data mengenai bidangbidang tanah yang akan didaftarkan daripada melalui pendaftaran tanah melalui sporadik, tetapi diperlukan waktu untuk memenuhi dana, tenaga dan peralatan. Sedangkan pelaksanaannya harus didasarkan pada suatu rencana pelaksanaan tahunan yang berkelanjutan, melalui uji kelayakan agar berjalan lancar. Pendaftaran tanah secara sporadik juga akan ditingkatkan pelaksanaannya karena dalam kenyataannya akan bertambah banyak permintaan untuk mendaftar secara individual dan massal yang diperlukan dalam pelaksanaan 
pembangunan yang akan semakin meningkat kegiatannya. ${ }^{5}$

$$
\text { Dalam melaksanakan }
$$

pendaftaran tanah, BPN dibantu oleh

Pejabat Pembuat Akta Tanah (PPAT)

dan Pejabat yang lainnya yang ditugaskan untuk melaksanakan kegiatan-kegiatan tertentu menurut Peraturan Pemerintah No. 24 Tahun 1997 ini dan peraturan perundangundangan yang bersangkutan. Misalnya dalam pendaftaran sistematik oleh Panitia Ajudikasi.

$$
\text { Panitia Ajudikasi tersebut }
$$
dibentuk oleh menteri Negara Agraria selaku Kepala BPN atau Pejabat yang ditunjuk. Pembentukan Panitia Ajudikasi dimaksudkan agar tidak mengganggu tugas rutin Kantor Pertanahan pada umumnya, sehingga pendaftaran tanah sistematik dapat diselenggarakan secara lebih cepat dan massal. Dalam melaksanakan tugasnya Panitia Ajudikasi dibantu oleh satuan tugas pengukuran dan pemetaan, satuan tugas pengumpul data yuridis dan satuan tugas administrasi yang tugas, susunan dan kegiatannya diatur oleh Menteri, kemudian tugas dan wewenang Ketua dan anggota Panitia Ajudikasi diatur oleh Menteri yang sesuai dengan peraturan - peraturan yang berlaku. ${ }^{6}$

Sesuai dengan Peraturan Menteri 3/1997 Pasall angka 8, Ajudikasi adalah kegiatan yang dilaksanakan dalam rangka proses pendaftaran tanah untuk pertama

5 Boedi Harsono, Seminar Nasional, Peraturan Pemerintah Nomor 24 Tahun 1997 Isi dan Penjelasannya, 1997, hlm 5

${ }^{6}$ Penjelasan Peraturan Pemerintah No. 24

Tahun 1997 Pasal 8 ayat 1 sampai dengan ayat 5, Tentang Pendaftaran Tanah kali, meliputi pengumpulan dan penetapan kebenaran data fisik dan data yuridis mengenai satu atau beberapa objek pendaftaran tanah untuk keperluan pendaftarannya. Hasil akhir dari proses pendaftaran tanah adalah penerbitan sertifikat oleh BPN yang didalamnya berisi data fisik dan data yuridis mengenai tanah. Data yuridis maksudnya ada keterangan mengenai status hukum bidang tanah yang didaftar, pemegang hak dan hak pihak lain serta beban-beban lain yang membebaninya. Bila dinyatakan sebagai status hukum bidang tanah yang terdaftar, berarti terdapat bukti yang menunjukkan adanya hubungan hukum antara orang dengan tanahnya. Adanya bukti hubungan hukum tersebut kemudian diformalkan (bukan dilegalisasi) melalui kegiatan pendaftaran tanah.

Dengan kata lain dalam kegiatan pendaftaran tanah terdapat tugas-tugas piñata-usahaan, seperti dalam hal penetapan hak atas tanah dan pendaftaran peralihan hak tanah. Bahkan dapat dikatakan bahwa kegiatan yang menyangkut aspek yuridis atau pengumpulan data yuridis sampai kepada penerbitan buku tanah, sertipikat dan daftar umum lainnya serta pencatatan perubahan di kemudian hari hampir seluruhnya menyangkut tugas-tugas administrasi. Dalam proses pengadministrasi-an kegiatan pendaftaran tanah tersebut, secara konkrit ditandai dengan adanya daftar-daftar isian yang diberikan kode-kode tertentu untuk mencatat setiap kegiatan dari pendaftaran tanah tersebut.

Berdasarkan uraian dari latar belakang yang telah dikemukakan 
diatas, maka perumusan masalah yang timbul dalam penelitian adalah sebagai berikut :

1. Bagaimanakah peran Ajudikasi dalam pendaftaran tanah?

2. Kendala - kendala yang di temukan dalam pendaftaran tanah dan cara penyelesaiaannya?

\section{Pembahasan}

\section{Peranan Ajudikasi dalam Pendaftaran Tanah Secara Sistematis}

Dalam

Peraturan

Pemerintah Nomor 24 Tahun 1997 tentang Pendaftaran Tanah ajudikasi adalah kegiatan yang dilaksanakan dalam rangka proses pendaftaran tanah untuk pertama kali, meliputi pengumpulan dan penetapan kebenaran data fisik dan data yuridis mengenai satu atau beberapa obyek pendaftaran tanah untuk keperluan pendaftarannya. Kegiatan ajudikasi pendaftaran tanah tersebut merupakan prosedur khusus yang dilakukan untuk pemberian status hukum atas bagian- bagian tanah kepada pemilik yang benar-benar berwenang. Didalam ajudikasi digunakan pola pendaftaran tanah sistematis yaitu secara masal dengan melakukan pola pemetaan dan penginventarisasian keseluruhan tanah yang ditentukan oleh pemerintah. Semua bidang tanah diukur dan diinventarisasikan kepemilikannya baik tanah bermasalah maupun tanah tanpa terkecuali dalam satu desa atau kelurahan.

Ada beberapa tugas penyelenggaraan pendaftaran tanah yang secara khusus dilakukan sesuai undang undang untuk pejabat lain selain Kepala Kantor Pertanahan.

BabIII pokok - pokok penyelenggaraan pendaftarana tanah jelaskan dalam Pasal 6 Ayat 1 yaitu : "dalam rangka penyelenggaraan pendaftaran tanah sebagai mana yang dimaksud dalam Pasal 5, tugas penyelenggaraan pendaftaran tanah dilakukan oleh Kepala Kantor Pertanahan, kecuali kegiatan-kegiatan lain yang oleh peraturan pemerintah dan undang- undang lainnya dapat ditugaskan kepada pejabat lain”. Maksud dari pasal diatas bahwa dalam melaksanakan proses pendaftaran tanah yang secara sistematis diperlukanlah satu anggota selain pejabat pertanahan, dalam hal ini panitia ajudikasi yang dibantu oleh pemerintah daerah desa/kelurahan yang bersangkutan, agar kiranya proses pendaftaran sejak awal sampai dikeluarkannya bukti kepemilikan bisa lebih baik dan benar, serta berjalan dengan lancar.

Hal - hal mengenai pembentukan panitia ajudikasi serta susunan, tugas, dan kewenangannya diatur lebih lanjut dalam Peraturan Menteri Nomor 3 Tahun 1997 Pasal 4854, Dalam melaksanakan tugasnya, Panitia Ajudikasi dibantu oleh satuan tugas 
pengukuran dan pemetaan, satuan tugas pengumpul data yuridis dan satuan tugas administrasi yang tugas, susunan dan kegiatannya diatur Menteri. Pada intinya tugas ajudikasi ini adalah tugas investigasi yang meneliti dan mencari kebenaran formal bukti, yakni data - data yuridis awal yang dimiliki pemegang hak atas tanah, dan tugas justifikasi, yaitu membuat penetapan dan pengesahan bukti yang sudah diteliti tersebut.

Susunan panitia ajudikasi terdiri dari seorang ketua panitia merangkap anggota yang dijabat olh seorang pegawai BPN. Beberapa orang anggota yang terdiri dari: Seorang pegawai Badan Pertanahan Nasional yang mempunyai kemampuan pengetahuan di bidang pendaftaran tanah. Seorang pegawai Badan pertanahan Nasional yang mempunyai kemampuan pengetahuan di bidang hak-hak atas tanah. Kepala Desa/Kelurahan yang bersangkutan dan atau seorang Pamong Desa/Kelurahan yang ditunjuknya. Selain itu, keanggotaan Panitia Ajudikasi dapat ditambah dengan seorang anggota yang sangat diperlukan dalam penilaian kepastian data yuridis mengenai bidang-bidang tanah di wilayah desa/kelurahan yang bersangkutan. ${ }^{7}$

Sesuai peraturan panitia ajudikasi mempunyai tugas dan wewenang dalam melaksanakan

${ }^{7}$ Peraturan Pemerintah No. 24 Tahun 1997, pasal 8 ayat $1-3$ pendaftaran tanah, diantara tugas dan wewenang Panitia Ajudikasi, yaitu: menyiapkan rencana kerja ajudikasi secara terperinci, mengumpulkan data fisik dan dokumen asli data yuridis semua bidang tanah yang ada di wilayah yang bersangkutan serta memberikan tanda penerimaan dokumen kepada pemegang hak atau kuasanya, menyelidiki riwayat tanah dan menilai kebenaran alat bukti pemilikan tanah atau penguasaan tanah, mengumumkan data fisik dan data yuridis yang sudah dikumpulkan, membantu menyelesaikan ketidaksepakatan atau sengketa antara pihak pihak yang bersangkutan mengenai data yang diumumkan, mengesahkan hasil pengumuman data fisik dan data yuridis yang akan digunakan sebagai dasar pembukuan hak atau pengusulan pemberian hak, menerima uang pembayaran, mengumpulkan dan memelihara setiap kwitansi bukti pembayaran dan penerimaan uang yan dibayarkan oleh mereka yang berkepentingan sesuai ketentuan yang berlaku, menyampaikan laporan secara periodik dan menyerahkan hasi kegiatan panitia ajudikasi kepada Kepala Kantor Pertanahan.

Penetapan batas bidang tanah yang sudah dipunyai dengan suatu hak yang belum terdaftar atau yang sudah terdaftar tetapi belum ada surat ukur/gambar situasinya atau surat ukur/gambar situasi yang ada tidak sesuai lagi dengan keadaan yang sebenarnya, dilakukan oleh Panitia Ajudikasi dalam 


\begin{abstract}
pendaftaran tanah secara sistematik atau oleh Kepala Kantor Pertanahan dalam pendaftaran tanah secara sporadik, berdasarkan penunujukan batas oleh para pemegang hak atas tanah yang bersangkutan dan sedapat mungkin disetujui oleh para pemegang hak atas tanah yang berbatasan. Dalam menetapkan batas- batas bidang tanah Panitia Ajudikasi terdaftar dan surat ukur atau gambar situasi yang bersangkutan. Bidangbidang tanah yang sudah ditetapkan batas-batasnya, diukur dan selanjutnya dipetakan dalam peta dasar pendaftaran.
\end{abstract}

Bidang tanah yang sudah dipetakan atau dibubuhkan nomor pendaftarannya pada peta pendaftaran dibukukan dalam daftar tanah. bagi bidang-bidang tanah yang sudah diatur serta dipetakan dalam peta pendaftaran, dibuatkan surat ukur untuk keperluan

pendaftaran haknya. ${ }^{8}$

Pendaftaran ini dibutuhkan bantuan satu panitia yang disebut panitia ajudikasi. Mengapa demikian, sebab pendaftarannya bersifat massal dan tidak mengganggu tugas rutin suatu kantor pertanahan. Sistematik itu sendiri menjelaskan satu kegiatan yang pertama kali dilakukan untuk mendata seluruh bidang - bidang tanah yang belum pernah dibukukan / disertifikatkan,yang prosesnya lebih cepat dan ditentukan

http://www.hukumproperti.com/2014/09/ 22/ajudikasi-pendaftaran-tanah. jangka waktunya atau Kepala Kantor Pertanahan memperhatikan batas - batas bidang atau bidang - bidang tanah.

Adapun

manfaat

pendaftaran tanah secara sistematik bagi pemilik hak atas tanah yaitu : prosedurnya mudah (Panitia datang ke lokasi), biaya murah, waktu cepat (Pengumuman 30 hari), memberikan kepastian hukum, memberikan rasa aman, harga tanah lebih mahal, dapat dijadikan jaminan hutang, memudahkan peralihan hak, penetapan Pajak Bumi dan Bangunan (PBB) tidak keliru.sedangkan manfaatnya bagi Pemerintah antara lain : terwujudnya tertib administrasi pertanahan, dapat mengurangi sengketa dibidang pertanahan, memperlancar kegiatan pemerintahan (jika perlu tanah, sudah ada datanya). Selain memiliki manfaat bagi pemilik hak atas tanah dan bagi pemerintah, pendaftaran tanah secara sistematis juga memiliki kelebihan diantaranya yaitu, pemegang hak atas tanah tidak perlu ke kantor pertanahan, bidang tanah yang didaftar sangat banyak karena massal, biaya murah, dan waktu pengumuman lebih singkat.

Pendaftaran tanah secara sistematik didasarkan pada suatu rencana kerja dan dilaksanakan di wilayah - wilayah yang ditetapkan oleh Menteri. Dalam hal suatu desa/kelurahan belum ditetapkan sebagai wilayah pendaftaran tanah secara 
sistematik

sebagaimana

dimaksud pada ayat (2), pendaftarannya dilaksanakan melalui pendaftaran tanah secara sporadik. Sedangkan pendaftaran tanah secara sporadik dilaksanakan atas permintaan pihak yang berkepentingan. Pendaftaran tanah secara sistematis memiliki dua dasar hukum yang digunakan dalam penerapannya, yaitu : Peraturan Pemerintah Nomor 24 Tahun 1997 Tentang Pendaftaran Tanah Pasal 1 angka 10, Pasal 8, 13-31 dan Peraturan Menteri Agraria/Kepala BPN Nomor 3 Tahun 1997 (Pelaksana Peraturan Pemerintah No.24 Tahun 1997) Pasal 46-72.

Adapun untuk memberikan kepastian hukum kepada para pemegang hak atas tanah, akan diberikan penegasan atas sejauh mana kekuatan pembuktian sertifikat yang dijadikan pegangan pembuktian akan hak tanah. Diberikan ketentuan bahwa selama belum dibuktikan yang sebaliknya, data fisik dan data yuridis yang tercantum dalam sertifikat harus diterima sebagai data yang benar, baik dalam perbuatan hukum seharihari maupun dalam sengketa dipengadilan, sepanjang data tersebut sesuai dengan apa yang tercantum dalam surat ukur dan buku tanah yang bersangkutan. ${ }^{9}$

${ }^{9}$ Peraturan Pemerintah No. 24 tahun 1997 Pasal 32 Ayat 1
2. Kendala - Kendala yang Ditemukan pada Pendaftaran Tanah Secara Sistematis dan Cara Penyelesainnya

Pendaftaran tanah secara sistematik lebih diutamakan karena melalui cara ini akan dipercepat perolehan data mengenai bidang-bidang tanah yang akan didaftarkan daripada melalui pendaftaran tanah melalui sporadik, tetapi diperlukan waktu untuk memenuhi dana, tenaga dan peralatan. Sedangkan pelaksanaannya harus didasarkan pada suatu rencana pelaksanaan tahunan yang berkelanjutan, melalui uji kelayakan agar berjalan lancar.

Pemerintah mengadakan pendaftaran tanah secara sistematis di kota Palu, dalam bentuk sebuah proyek yang dikenal dengan prona, dimana pada prona ini pemerintah memberikan kemudahan dalam mendaftarkan tanah bagi rakyat dengan ekonomi menengah kebawah, dibandingkan dengan pendaftaran tanah secara sporadik, pendaftaran tanah secara sistematis melalui program seperti ini sangat membantu masyarakat kecil dalam mendaftarkan tanah mereka sebab segala beban biaya ditanggung sepenuhnya oleh Pemerintah, dimana anggaran yang digunakan dalam program tersebut berasal dari APBN dan pinjaman dana dari World Bank. ${ }^{10}$

${ }^{10}$ Eli Noviyanti, S.St, Panitia Pendaftaran Tanah, Tanggal 15 Januari 2019 
Pendaftaran tanah secara sistematis memerlukan biaya yang tidak besar namun membutuhkan waktu yang lama, karena pendaftaran tanah sistematis dalam bentuk prona hanya dilaksanakan sekali dalam setahun. Selain hanya dilaksanakan sekali dalam setahun, prona juga terbilang kurang disosialisasikan oleh pemerintah setempat kepada masyarakatnya sehingga masyarakat tidak mendapatkan informasi yang jelas, akibatnya ialah masyarakat tidak mengetahui bagaimana sistem yang digunakan dalam pendaftaran tanah tersebut, syarat - syarat apa saja yang harus dilengkapi dalam mendaftarkan tanah mereka, dan apa saja proses yang harus dilalui oleh masyarakat agar tanah mereka mendapatkan sertifikat sehingga memiliki kepastian hukum atas tanahnya.

Oleh karena kurangnya sosialisasi dari pemerintah dan kurangnya pemahaman masyarakat terhadap pendaftaran tanah sistematis, maka masyarakat berinisiatif mendaftarkan sendiri tanahnya ke Kantor Pertanahan melalui pendaftaran tanah secara sporadik, meskipun pendaftaran tanah secara sporadik membutuhkan biaya yang sangat mahal.

\section{Simpulan}

Didalam ajudikasi digunakan pola pendaftaran tanah sistematis yaitu secara massal dengan melakukan pola pemetaan dan penginventarisasian keseluruhan tanah yang ditentukan oleh pemerintah. Semua bidang tanah diukur dan diinventarisasikan kepemilikannya baik tanah bermasalah maupun tanah tanpa terkecuali dalam satu desa atau kelurahan. Dalam melaksanakan tugasnya, Panitia Ajudikasi dibantu oleh satuan tugas pengukuran dan pemetaan, satuan tugas pengumpul data yuridis dan satuan tugas administrasi yang tugas, susunan dan kegiatannya diatur Menteri. Sistematik itu sendiri menjelaskan satu kegiatan yang pertama kali dilakukan untuk mendata seluruh bidang - bidang tanah yang belum pernah dibukukan / disertifikatkan, yang prosesnya lebih cepat dan ditentukan jangka waktunya.

Adapun manfaat pendaftaran tanah secara sistematik bagi pemilik hak atas tanah yaitu : prosedurnya mudah (Panitia datang ke lokasi), biaya murah, waktu cepat (Pengumuman 30 hari), memberikan kepastian hukum, memberikan rasa aman, harga tanah lebih mahal, dapat dijadikan jaminan hutang, memudahkan peralihan hak, penetapan Pajak Bumi dan Bangunan (PBB) tidak keliru. Pendaftaran tanah secara sistematik lebih diutamakan karena melalui cara ini akan dipercepat perolehan data mengenai bidang- bidang tanah yang akan didaftarkan daripada melalui pendaftaran tanah melalui sporadik, tetapi diperlukan waktu untuk memenuhi dana, tenaga dan peralatan. Sedangkan pelaksanaannya harus didasarkan pada suatu rencana pelaksanaan tahunan yang berkelanjutan, melalui uji kelayakan agar berjalan lancar. 
Pendaftaran tanah secara sistematis memerlukan biaya yang tidak besar namun membutuhkan waktu yang lama, karena pendaftaran tanah sistematis dalam bentuk prona hanya dilaksanakan sekali dalam setahun. Selain hanya dilaksanakan sekali dalam setahun, prona juga terbilang kurang disosialisasikan oleh pemerintah setempat kepada masyarakatnya sehingga masyarakat tidak mendapatkan informasi yang jelas, Oleh karena kurangnya sosialisasi dari pemerintah dan kurangnya pemahaman masyarakat terhadap pendaftaran tanah sistematis, maka masyarakat berinisiatif mendaftarkan sendiri tanahnya ke Kantor Pertanahan melalui pendaftaran tanah secara sporadik, meskipun pendaftaran tanah secara sporadik membutuhkan biaya yang sangat mahal.

\section{Saran}

1. Pemerintah sebaiknya lebih gencar lagi dalam mensosialisasikan pendaftaran tanah sistematis terlebih kepada masyarakat yang tergolong miskin, agar mereka mengetahui dan memahami secara jelas apa pendaftaran tanah sistematis tersebut, bagaimana sistem yang digunakan dalam pendaftaran tanah sistematis, syarat-syarat apa saja yang harus dilengkapi dalam mendaftarkan tanah mereka, dan apa saja proses yang harus dilalui oleh masyarakat agar tanah mereka mendapatkan sertifikat sehingga memiliki kepastian hukum atas tanahnya. Sehingga masyarakat miskin tersebut mendapatkan kemudahan dalam mendaftarkan tanahnya dan mereka tidak perlu lagi mengeluarkan biaya yang besar dalam mendaftarkan tanah melalui pendaftaran tanah sporadik.

2. Sebaiknya pendaftaran tanah secara sporadik biayanya sedikit dikurangi bagi masyarakat ekonomi menengah ke bawah agar mereka dapat kemudahan dari segi biaya sebab bila hanya mengharapkan bantuan dari pemerintah melalui pendaftaran tanah sistematis tentu ini membutuhkan waktu yang lama karena pendaftaran tanah sistematis hanya diadakan sekali dalam setahun.

\section{DAFTAR PUSTAKA}

\section{Literatur}

A.P. Parlindungan, Pendaftaran Tanah di Indonesia, Mandar Maju, Bandung, 1999, Boedi Harsono, Seminar Nasional, PP Nomor 24 Tahun 1997 (Isi dan penjelasannya),1997.

Boedi Harsono, Hukum Agraria Indonesia : Sejarah Pembentukan Undang-Undang

Pokok Agraria, Isi dan
pelaksanaanya,
Jakarta:Djambatan,
Supriadi, Hukum Agraria, Sinar
Grafika, Ctk. Pertama, Jakarta,
2007,


Supriadi, Hukum Agraria, Sinar Grafika, Ctk. Kedua, Jakarta, 2008,

\section{Perundang-Undangan}

Peraturan Pemerintah Nomor 24 Tahun 1997, Pasal 8 Ayat 1 sampai dengan Ayat 5,Tentang Pendaftaran Tanah.

Peraturan Pemerintah, No 24, Tahun,1997 (Pasal 8 Ayat 1-3). Peraturan Pemerintah No. 24 Tahun 1997 (pasal 32 ayat 1)

Peraturan Dasar Pokok-pokok Agraria, UU No. 5, LN No. 104 Tahun 1960, TLN No. 2043, psl. 19.

\section{Website}

https://id.wikipedia.org/wiki/Kabupat en_Kudus

http://www.hukumproperti.com/2014 /09/22/ajudikasi-pendaftarantanah. 